\title{
escola, problemas de escuta?
}

\author{
steferson zanoni roseiro ${ }^{1}$ \\ universidade federal do espírito santo, brasil \\ orcid id: https://orcid.org/0000-0003-1424-2281 \\ nahun thiaghor lippaus pires gonçalves ${ }^{2}$ \\ universidade federal do espírito santo, brasil \\ orcid id: https://orcid.org/0000-0002-5684-0880 \\ alexsandro rodrigues ${ }^{3}$ \\ universidade federal do espírito santo, brasil \\ orcid id: https://orcid.org/0000-0002-5998-4978
}

resumo

Este artigo, apresentando o enviesamento da escuta como um problema comum nas escolas, objetiva discutir os modos pelos quais falas, manifestações e discursos estudantis são afinados a ponto de perderem sua força imanente. Afirmando haver uma insistência em afinar as escutas nas escolas mesmo com base em teorias pedagógicas, o texto aponta, na contramão, para enunciações pouco usuais de estudantes como um dever ético. No plano das dissonâncias, encontra-se, na verdade, uma cacofonia de vozes produzindo as mais infinitas possibilidades de escola. E isso, justamente, é o que assusta esses corpos tão certos de suas pedagogias. Metodologicamente, essa pesquisa acompanhou o contexto de duas escolas municipais do estado do Espírito Santo, criando redes de conversações entre estudantes e professores. Assim, apostando na perspectiva de uma escuta distraída, o artigo propõe não dar vazão apenas aos silenciamentos ou às escutas perversas, mas, antes, opta por apontar de que modo outras falas reverberam produzindo certas insurreições. Os insurgentes atravessam a linearidade aos risos e aos saltos, riem-se de todo o desejo libertário. Na insurreição, liberdade é a possibilidade de fazer contágio com outros corpos. Se as escutas pedagógicas dão preferências a certas alunas e alunos, é preciso enxergar ali, nos corpos menos prestigiosos, um arrombo de escuta incontrolável.

palavras-chave: escola; escuta; insurreição.

\section{school, listening problems?}

abstract

This essay presents the oblique listening as a usual problem in schools, it aims to discuss the ways students' speeches, manifestations and discourses are tuned to the point of losing their immanent strength. Affirming that there is some insistence on tuning the listening in schools even in pedagogical theories, this text points to unusual students enunciations as an ethical duty. In the dissonance field, a cacophony of voices find itself producing infinite possibilities. This is exactly what scares these bodies so right about their pedagogies. Methodologically, this research took place in two public schools in the state of Espírito Santo, creating conversations network with students and teachers. Therefore, gambling on the perspective of a distracted listening, the essay proposes to pay attention not only to the silences or to the wicked listening, but first it appeals to point to other speeches that reverberate producing some insurrection. The insurgent ones cross the

\footnotetext{
1 E-mail: zanoniroseiro@hotmail.com

2 E-mail: nahunthiaghor@gmail.com

${ }_{3}^{3}$ E-mail: xela_alex@bol.com.br
} 
linearity laughing and jumping, laughing giggling about all libertarian desire. In the insurrection, liberty is the possibility of making a contagion with other bodies. If the pedagogical listening focus on some students, the goal is to see, in less prestigious bodies, the crack on the ungovernable listening.

keywords: school; listening; insurrection.

\section{¿escuela, problemas de escucha?}

resumen

Este ensayo presenta la escucha sesgada como un problema habitual en las escuelas, pretendiendo discutir de qué manera los discursos, las manifestaciones y los discursos de los estudiantes se sintonizan hasta el punto de perder su fuerza inmanente. Afirmando que hay cierta insistencia en ajustar la escucha en las escuelas, incluso en las teorías pedagógicas, este texto apunta a enunciaciones inusuales de los estudiantes como un deber ético. En el campo de la disonancia, la cacofonía de voces encuentra a si misma produciendo infinitas posibilidades. Y esto es exactamente lo que asustan a estos cuerpos tan ciertos de su pedagogías. Metodológicamente, esta investigación se llevó a cabo en dos escuelas públicas en el estado de Espírito Santo, creando una red de conversaciones con estudiantes y maestros. Por lo tanto, al apostar en la perspectiva de una escucha distraída, el ensayo propone prestar atención no solo a los silencios o a la escucha perversa, sino que primero apunta a otros discursos que reverberan produciendo cierta insurrección. Los insurgentes cruzan la linealidad riendo y saltando, riéndose de todo deseo libertario. En la insurrección, la libertad es la posibilidad de hacer contagio con otros cuerpos Si la escucha pedagógica se enfoca en algunos estudiantes, el objetivo es ver, en cuerpos menos prestigiosos, la grieta en la escucha ingobernable.

palabras clave: escuela; escucha; insurrección. 
escola, problemas de escuta?

escola, problemas de escuta?

\section{cobrir as orelhas! ou brincar de telefone sem fio?}

"De onde vem essa gritaria toda", perguntou uma professora na coordenação. “De onde mais?", respondeu a coordenadora, “Da mesma sala de sempre".

Em uma escola, ocorrem duas assembleias de estudantes ao longo de um ano; noutra escola, nada. Numa escola, o grêmio estudantil começa a se formar, turmas começam a se organizar para fazer chapas e propostas; noutra, nada. Nas duas escolas, o primeiro trimestre termina com eleição de representantes de turmas. E, como em toda escola, muitos dramas, muitas histórias, muitas reclamações. "Aqui é assim, sabe? Todo dia é desse mesmo modo: chegam muitas mães, ficam ali esperando para poder conversar com qualquer um que parar na reta delas. Então, só aviso: toma cuidado! Elas reclamam com o primeiro que passa".

E, efetivamente, os dias na escola dessa coordenadora se consagram com a primeira hora diária sendo usada para atender familiares os mais diversos, com conversas as mais distintas entre reclamações e pedidos de ajuda. Logicamente, uma via de mão dupla entre escola e comunidade.

Se pensarmos no cenário apresentado, diríamos, quase, haver uma boa rede de escutas nas escolas. Afinal, nem toda escola faz suas assembleias estudantis, tampouco possui grêmio organizado ou representantes escolhidos em tempo hábil. Parecemos falar, a bem da verdade, de duas escolas que, logicamente, apresentam seus problemas usuais da vida escolar, mas que, ainda assim, encontram modos de lidar com esses desvios, com essas tramas quase novelescas.

Infelizmente, não é bem assim.

Independentemente da escola, se você fosse um aluno que, durante todo o ano letivo, reclamasse da mesma coisa - "Nosso banheiro não tem porta" - e o problema persistisse, ou, quem sabe, se você aprontasse muitas brincadeiras no recreio e, entre uma e outra confusão, fosse colocado num canto do corredor, calado, você - em ambos os casos - seria o problemático. 
Informamos a todos: esses alunos com passagem permanente na coordenação não podem ser levados a sério. Isso é válido para tudo o mais que não gostamos, desde os alunos que falam de coisas aleatórias sem parar na sala até aqueles que sabem demais e enchem a paciência com isso. Ou mesmo para aquele aluno que simplesmente brinca demais.

Não tem como levar essas crianças a sério.

Se essas crianças tomassem uma boa dose de calmantes ou remédios da linha zumbilike, talvez elas fossem ouvidas. Mas, enquanto problemáticos, dar atenção fica sempre mais difícil. Quem quer ouvir o aluno ou a aluna que o aporrinham o tempo inteiro? Na qualidade de professoras e professores, sabemos que, diante de alguns alunos, o melhor é desligar todos os canais sensitivos e deixá-los falar. "Sabe o que eu quero fazer final de ano? Ligar o mudo de cada criaturinha que vejo e dar minha aula. Só isso!".

Infelizmente, para muitos de nós, essa seria, simplesmente, a mais salvadora das propostas. Bastaria que os alunos se calassem, bastaria que nada mais eles perturbassem e pronto, a escola poderia voltar a ser o que - segundo eles - ela já foi um dia. Tornando inaudível qualquer possibilidade de falar dos corpos estudantis, a escola voltaria a ser sinônimo de esplendor, voltaria a sua era dourada, em que alunos entrariam como alunos e sairiam bons cidadãos.

Essa fala, decerto, se alastra em todas as escolas. Convivemos com elas e sabemos bem disso. E sua circularidade é tão louca, que, de algum modo, até um presidenciável, em 2018, teve coragem de repercuti-las em suas propostas de governo.

E as falas seguiam de um ouvido a outro, esbarrando entre as paredes do conselho de classe, em que são paulatinamente interpretadas, subvertidas, justificadas, invisibilizadas, até que um grito ecoasse entre as vozes professorais: "Precisamos ouvi-los, não criticá-los!".

O tom da conversa muda.

No momento em que todos querem ter razão, escutar a criança emerge como pauta. Há, em demasia, falas encharcadas de razão de professoras e professores, coordenadoras, diretoras e pedagogas que insistem em interpretar, em 
escola, problemas de escuta?

ajuizar as falas emergentes em uma assembleia, um corredor, uma fila, um pátio, uma sala. Para onde olhássemos, as escutas eram radicalmente pervertidas em justificavas, explicações e réplicas. "Já reparou que nenhum dos seus outros colegas reclama desse professor? Que só você faz isso? E aí me fala como eu vou acreditar no aluno que tem mais passagens pela coordenação do eu que sou coordenadora?".

Em um segundo, qualquer fala pode ser pervertida e extraviada.

Ao longo de 2018, estivemos em duas escolas públicas municipais no estado do Espírito Santo, acompanhando o desenrolar de suas atividades entre maio e setembro. Realizamos a estratégia das redes de conversações (CARVALHO, 2006) com grupos de discentes e docentes em diferentes momentos, propondo problematizar as histórias de ambos os lados. Preocupados com questões infinitas relacionadas aos estudantes, desenvolvemos, nessas duas escolas, registros textuais (histórias e registros das falas) e imagéticos (desenhos e pinturas das situações vividas nas escolas) - de como alunas e alunos passam a borrar ou desobstruir regras escolares demasiado controladoras ${ }^{4}$.

Eis, justamente, nossa proposta neste texto: traçar um mapa das falas continuamente pervertidas, ou, antes, dos problemas de escuta das escolas. Carvalho e Roseiro (2015) diziam que alguns corpos-alunos, porque tornados nus na lógica agambeniana, deixavam de ser alunos para serem corpos julgáveis. Todavia, o que nos interessa, neste artigo, não é a força do julgamento ou do estado de exceção, mas, antes, dos corpos indóceis, da nudez que, mesmo sendo política, vira também artística. Esses corpos, porque desacreditados, falam sem parar das regras e das mazelas do poder; esses corpos, porque desacreditados, fazem combates e insurreições, organizam-se taticamente para criar canais de escuta infalíveis. Alguns de nós, nas escolas, podemos até não querer ouvi-los, mas, para o infortúnio deles, esses corpos são a definição da vagabundagem

\footnotetext{
${ }^{4}$ Ao longo do texto, optamos por não trabalhar com modos de identificação das falas por acreditarmos que, diante da lógica identitária, as falas e histórias produzidas parecem estanques ou situacionais. Noutra direção, apostamos em uma perspectiva em que a fala pode transitar entre os corpos. Não interessa se uma fala é dita, em uma ou em outra escola, por uma diretora ou coordenadora; interessa, antes, que essas falas ganhem força por sua circularidade, por sua carga viral.
} 
(DELIGNY, 2018) e da insurreição (COMITÊ INVISÍVEL, 2016). Com eles, é possível pensar a escuta distraída como princípio da escola (LARROSA, 2014).

A escuta, aqui, não é opcional.

\section{arrombo da humanidade}

Encontramos, em todas as escolas, um conjunto de corpos que não conseguem controlar-se, inaptos, desde sua matrícula, a serem corpos-alunos. As famílias fazem suas investidas de alunização tanto quanto os professores, os pedagogos, as serventes, os vereadores e quem mais passar por essas instituições. Tentam alunizar essas crianças de atender a um padrão socioescolar. Interessa que a humanidade savianística (Saviani, 2011) seja produzida e, para isso, os alunos precisam ser ensinados pelos grão-duques do saber, aqueles que, evidentemente, conhecem os clássicos e garantem a qualidade do ensino via criação dos autômatos-estudantis, aptos a imitar o que lhes é exigido.

Isto é: na lógica de algumas pedagogias, interessa que a criança seja crítica, mas, ao mesmo tempo, ela reconheça que são os adultos que sabem. Para Saviani, deve-se, sim, ouvir, mas sempre em um sentido único. O saber se concentra naquele que se apropriou mais densamente da humanidade, naquele que foi hábil em explorar e conhecer os saberes científica e historicamente reconhecidos como clássicos para a vida.

Na lógica da produção de humanidade, o outro - o não humano - é sempre subalterno ao humano, é objeto manipulável pelo ser dito pensante.

No antropocentrismo, o humano é a figura do saber.

E isso muito nos assusta.

A escola, enquanto produção de humanidade, implica justamente essa figura do humano no centro do universo, ou, ao menos, como aquele que configura o seu entorno para fabricá-lo. Em Saviani (2011), por exemplo, vemos o enaltecimento do trabalho intencional do professor que ensina a transformar o não humano (animal, vegetal, mineral, teórico, político etc.) em ferramentas para o humano. O humano é ressaltado tal qual no ensaio de Friedrich Engels (2006), em 
escola, problemas de escuta?

O papel do trabalho na transformação do macaco em homem, isto é, o humano afirma-se no ser capaz de usar os recursos disponíveis para fins próprios.

Não discordamos desse conceito de humano, mas, antes, leitores de Gilles Deleuze e Félix Guattari (2011), destacamos que essa característica não é unicamente humana. Também as máquinas fazem isso a torto e a direito.

A máquina e os agenciamentos maquínicos em Deleuze e Guattari antecedem, coexistem e existirão mesmo depois do humano. A máquina produz fluxos, desejos, forças, estratégias e mesmo relações entre corpos humanos ou não humanos. Para os autores, as máquinas existem em todas as direções e produzem a todo o tempo. A vida animal, vegetal, mineral, entre outros, segue fluxos maquínicos e, ao mesmo tempo, se inscreve e altera esses fluxos continuamente. Insetos se cruzam tanto com vegetais quanto com minerais, para produzir vida tanto quanto o humano, que se vale de rochas e teorias para manter-se lúcido.

A questão deleuzo-guattariniana é que, para onde olhemos, vemos relações intrincadas entre humanos e não humanos, e não nos é possível ver uma relação tão centralizada quanto desejariam algumas teorias.

Antes e depois de qualquer humano, há musicalidade, afetos, jogos de poder, desejos, paixões, imitações, devires, mutabilidades, vidas. O humano é um dos elementos que compõem a vida e não é seu centro. Na lógica maquínica, o humano relaciona-se com todos esses outros elementos e dificilmente é capaz de ser separado do que não é humano. Ou, como Lazzarato (2014, p. 35) destaca, mesmo "em nossas ações mais 'humanas' (falar, comunicar, escrever, pensar etc.) somos 'assistidos' por uma nova geração de máquinas".

E a máquina, conforme lembram Deleuze e Guattari (2011), nada mais é do que o agenciamento que mantém a vida funcionando. Isto é, máquinas são motes que interligam corpos, pensamentos, desejos, modos de existir e trabalhar, mantendo tudo isso mais ou menos organizado. Uma máquina não para de produzir modos de operações e não pode existir sozinha. Estando sempre interligada a outras máquinas, é quase impossível de referenciá-las, todavia as vemos a todos os momentos. 
Assim, se a questão para Engels era a de humanização a partir de nossa transformação dos arredores em ferramentas, a conceituação maquínica da vida propõe pensar no quanto os limites do humano não são tão detectáveis quanto o antropocentrismo prevê.

Daí, justamente, a ironia do conto de Franz Kafka (1999), intitulado Um relatório para a academia. Levando a proposta de Engels - e posteriormente aprimorada por Karl Marx - ao limite, Kafka faz de um símio um humano em todas as suas capacidades pelo simples fato de que, apenas imitando o humano, o animal consegue fazer-se presente. $\mathrm{O}$ animal logo percebe: não há a possibilidade de fuga nem liberdade; então, o humano é sua única alternativa.

Essa nos é uma crítica peculiar.

Se a escola savianística visa produzir em cada pessoa a humanidade historicamente sistematizada, o conceito gerador de humanidade aqui é simplesmente o de conhecimento dos saberes acumulados ao longo da história humana e de sua imitação/apropriação. Faríamos uma escola de excelência se conhecêssemos tudo o que nossos antepassados produziram e conheceram. É claro, não acreditamos que os grupos da pedagogia histórico-crítica tenham essa perspectiva reprodutivista como objetivo final; estamos cientes de que, a todo o momento, Demerval Saviani e seu grupo clamam por liberdade e lutas de classe. Contudo, para jogar esse jogo, eles se submetem a um humanismo que não dá conta de outras formas de vida, que não dá conta das garatujas maquínicas, dos sons animalescos. Eles clamam por liberdade, mas de modo demasiado controlado e controlador.

O corpo produzido nessa pedagogia é do humano autocentrado. Falta-lhe, como destacava Lazzarato (2014), a percepção do maquínico; e, ao mesmo tempo, Brian Massumi (2017) vai destacar: falta-lhe a intuição animalesca.

No animal, o jogo gira em torno da brincadeira e da capacidade de criar sons afetivos.

Em seu conto, Kafka zomba o humano em seu sentido de reduzir os ruídos dos sons assignificantes, dos rugidos e das gagueiras - "Conforme me disseram, devo ter feito muito pouco barulho, donde se concluiu que ou iria perecer logo ou 
escola, problemas de escuta?

que, caso conseguisse sobreviver aos primeiros tempos críticos, ficaria bastante apto a me amestrar" (KAFKA, 1999, p. 63) -, é justamente porque há uma crítica necessária a ser feita sobre a redução das sonoridades a falas.

Não é necessária nenhuma interpretação: o humano é aquele que permanece quando as cacofonias são reduzidas a linguagens cognoscíveis.

Seguindo os rastros kafkianos, Gilles Deleuze e Félix Guattari (2014) e Brian Massumi (2017) vão dizer justamente sobre o balburdio animalesco que, sob nenhuma hipótese, pode ser humanizado. O animal, destaca Massumi (2017), não é o ser irracional ou mesmo o sem intencionalidade como o antropocentrismo apregoa. A vida animal, anuncia o autor, propõe modos afetivos de se relacionar que nós, humanos, parecemos ter esquecido. Em seu livro $O$ que os animais nos ensinam sobre política, o filósofo procura na biologia apontamentos de pensar a brincadeira como um dos modos mais políticos de estar na vida. Segundo ele, o brincar não é uma imitação simplória da vida adulta. Brinca-se para expandir as capacidades cognitivas, para que o corpo aprenda, de modo intuitivo, aquilo que o pensamento pode demorar para processar.

$\mathrm{Na}$ brincadeira animalesca, dois corpos se colocam em um estado afetivo em que os limites do real são borrados no abanar de rabo, no bater de antenas de uma cigarra ou no eriçar de penas de um pássaro. Os animais, completamente alheios aos objetivos ou à intencionalidade, brincam não visando a algo; sendo assim, a brincadeira se consagra no afeto brincante, no modo como um animal encara o outro e o convoca àquele tempo inevitavelmente "perdido". Ambas as partes envolvidas se sabem brincantes e, por isso, não produzem afeto além de modos expansivos de existir.

Em miúdos, brinca-se para ultrapassar qualquer limite do real.

De modo similar, embora em outra direção, Deleuze e Guattari (2014) apontam que os animais, apesar de incapazes de enunciar falas compreensíveis ao humano, produzem sons coerentes com suas capacidades políticas e isso nada tem a ver com um rato que entende outro rato. Essa afirmação poderia ser feita por qualquer biólogo. Antes, leitores da animalidade kafkiana, os autores afirmam que a questão é produzir um som tão radicalmente político-afetivo, que toda e 
qualquer forma de vida seja afetada por essa sonoridade, sejam pedras, animais, plantas, humanos, máquinas, pensamentos etc.

Uma vez que os animais perdem a capacidade - de produzir sons grosseiros e afetivos, de gingar na brincadeira - e passam a inserir nas relações a tal intencionalidade que a tudo objetifica, tal qual o símio do conto de Kafka, eles percebem: “É tão fácil imitar as pessoas!” (KAFKA, 1999, p. 59).

Eis, então, crianças comportadas, ou, antes, as crianças que imitam com perfeição o ideal de humano em uma sala de aula.

O professor criado pelas pedagogias geralmente é não apenas o dono do saber como na história criada por Manoel de Barros e Martha de Barros (2007), isto é, a figura de uma pessoa bonachona e cheio de certezas, a Dona Lógica do Saber. Não, para a maioria das lógicas pedagógicas, exige-se que o professor seja o adulto responsável, seja aquele que esteja sempre certo - ou ao menos que tenha controle sobre seus erros -, que mantenha uma postura neutra diante de seus alunos e dos saberes e que, afinal de contas, tenha sempre uma palavrinha extra para falar, dando, assim, o tom da moral da história.

Esses professores tão bem-intencionados vão ainda mais longe: se Saviani lhes dá todo o acorde para serem os donos do saber, Lev Vigotski (2012), como maestro, rege o coral das vozes que podem ser ouvidas e das outras, as anormais, que devem, no máximo, fazer o coro.

Nessas escolas, os professores, mediando esse coral depravado, sujeitam cada pequena voz de acordo com o que as bases curriculares dizem ser viável ou não. E para cada voz demasiado grave ou fina e para cada aluno desafinado ou áfono eles criam regras de tratamento para a anormalização das crianças. Se, em Vygotsky (2012), o anormal podia ser compensado, na nova onda de crianças anormais, a compensação é desvirtuada alto e bom som: “Eu já falei que não quero ouvir sua voz".

Nenhum professor, em particular, diz essa frase, mas, a todo o momento, ouvimos esse bordão nas escolas.

Na melhor das hipóteses, as escutas desses corpos são afinadas. 
escola, problemas de escuta?

\section{o volume do coral}

Existe escuta para além da mordaça? Das salas "produtivas" em que só se ouve o pincel sendo riscado no quadro, ou, no máximo, as respostas corretas às perguntas? A escuta escolar é sempre uma questão de interpretação, mediação e intervenção?

Jorge Larrosa (2014) sugere pensar as crianças como produtoras de barulho, de algazarra. Para o autor, as conversas atravessadas seriam corpos produzindo afetos, relações de cuidado, de atenção, de brincadeiras e de sentidos. As crianças que, em sala, copiam conversando, cantando, implicando com outras nada fazem senão entrar em possibilidades de escutas. A sala do "auê", da bagunça ou da fofoca faz sucesso não por ser espaço em que professoras e professores não fazem nada, mas porque ali as possibilidades são ampliadas. Assim, um corpo não entra numa conversa bem-intencionado - a intenção da escuta, para ele, não presta para muita coisa! -, antes, entra "distraidamente, quer dizer, com uma atenção tensionada ao máximo, mas se mantendo como atenção pura, como uma tensão que não está normatizada pelo que sabemos, pelo que queremos, pelo que buscamos ou pelo que necessitamos" (LARROSA, 2014, p. 38).

Talvez seja essa escuta distraída que faça, por exemplo, um professor chegar ao fim do ano letivo e escrever uma carta para cada um de seus alunos. Uma carta simples, sem muitas pretensões, apenas com um texto falando de coisas boas e bobas de cada criança. Talvez isso também tenha a ver com um professor que, vendo muitos de seus alunos preferirem passar o tempo de recreio na sala, pensa em montar um corredor com muitos livros espalhados pelas paredes, convidativo até para aqueles tachados de "alunos especiais".

Ora, mas, se voltamos à função da escola, tudo está mais que claro: essas escutas são demasiado despreocupadas com o futuro da humanidade. Se a escola tem a responsabilidade social de produzir o humano a partir dos saberes historicamente sistematizados, há de se reconhecer a figura da professora e do professor como aquele que sabe. "No cheio do saber, não pode brotar nada" (LARROSA, 2014, p. 44). 
Entra em questão o complexo de modelagem que cabe ao professor, modelador de respostas, conceitos, falas, escutas e, inclusive, silêncios. "É o segredo dos bons mestres: com suas perguntas, eles guiam discretamente a inteligência do aluno - tão discretamente, que a fazem trabalhar, mas não o suficiente para abandoná-la a si mesmo" (RANCIÈRE, 2013, p. 51), pois, nessa perspectiva, a escuta necessariamente é afinada.

A boa sala de aula, para essa escuta afinada, é aquela que tem um professor encarnando o mestre socrático em cada fala: muita pose, muita fala, muitas perguntas e respostas pré-programadas, lançadas em sequência.

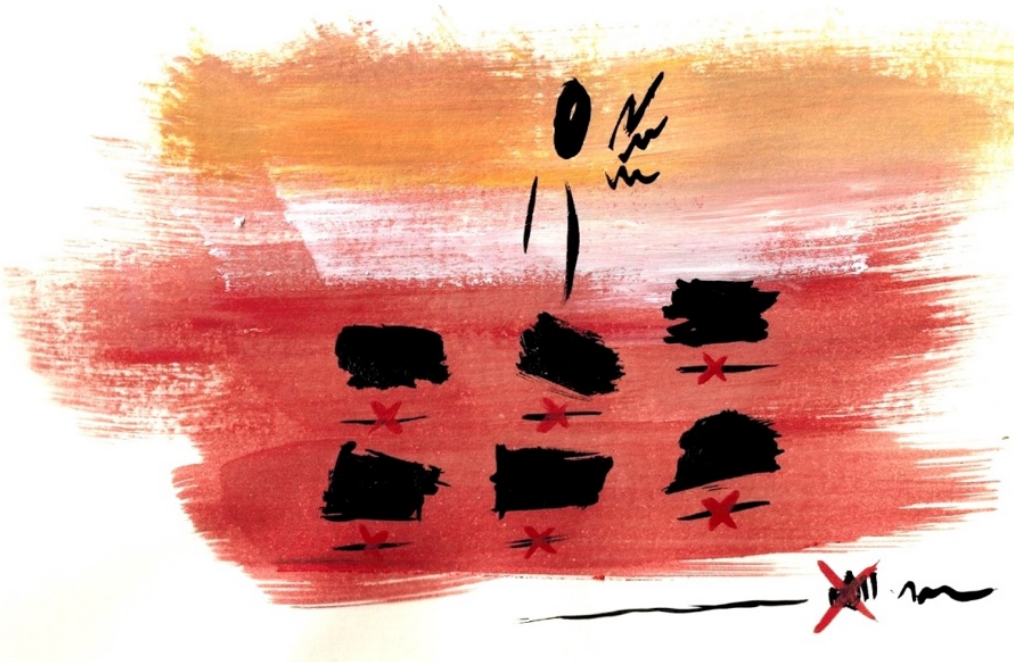

Imagem 02 - Escuta afinada.

Luiz Antônio Baptista (1997) falava de amoladores de facas como aquela figura pública que, discursando, acaba por nutrir ódio alheio. De modo análogo, talvez vejamos essas escutas afinadas como amoladores de facas que dizem quais saberes são viáveis e quais não. E, quanto mais afinada, mais competitiva fica a história.

No refinamento do coral, todos competem para ser maestro.

Se a criança não é afinada pela professora, ela é por sua turma que a engolfa no coral das vozes bonitas. Se, de algum modo, escapa aos colegas, é logo mandada à coordenação, onde a coordenadora, com voz de tenor, já vai logo anunciando a tragédia da opereta. Na persistência, as famílias são chamadas ao 
escola, problemas de escuta?

camarim com seus pedidos inconsoláveis de misericórdia, de apoio redentor. E, se ainda se fizer audível em tom cacofônico, será, então, chamada a equipe pedagógica superior com suas múltiplas técnicas e instrumentos que, no fim, funcionam como apps de afinamento - por dois dias -, e as crianças não mais incomodam com suas vozes destoantes.

Mas, por favor, não fiquemos apenas na lógica do afinamento.

No plano das dissonâncias, encontramos, na verdade, uma cacofonia de vozes produzindo as mais infinitas possibilidades de escola. E isso, justamente, é o que assusta esses corpos tão certos de suas pedagogias. Numa escola onde uma turma faz, no fim do ano, uma lista de coisas legais e de coisas que ela não gostaria de repetir, a diretora, convidada para ver os elementos da lista, opta por fazer uma audiência imediata entre alunos e professores acusados. O problema é que, nessa conversa, apenas os professores puderam responder; afinal, as falas dos alunos estavam já no quadro, bem registradas e detalhadas.

O professor da turma pareceu morrer diante do julgamento.

Noutra escola, as alunas e os alunos reclamam, em uma assembleia, contra as preferências dadas às professoras e aos professores no refeitório. Reunidas, as crianças falaram sobre a incoerência de professores ganhando as melhores comidas, enquanto os alunos eram relegados às porções menores, frias e cruas. "É proibido isso, gente, vocês vão fingir que não lembram?", bradou uma das alunas na assembleia.

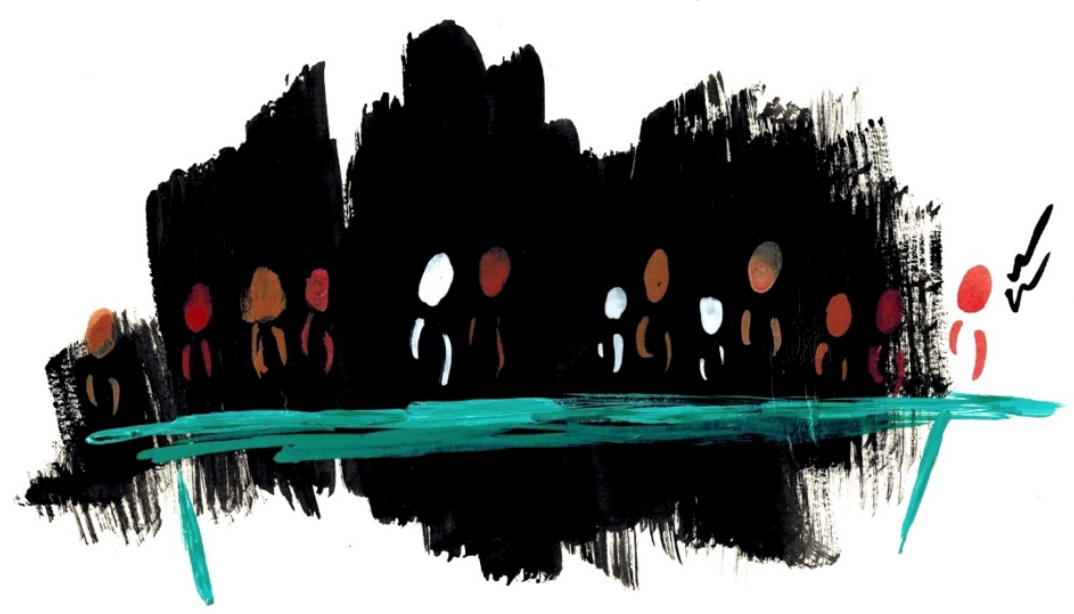

Imagem 01 - A Santa Assembleia. 
A resposta do corpo docente foi: "Vamos averiguar".

O ano letivo acabou, e o resultado da audição foi arquivado.

Esses dois casos, entretanto, não morrem assim.

As escutas, quando possíveis, provocam mudanças no plano do curso da vida. Diante do tom acusatório da aluna, alguns professores começaram a ir para o recreio com as crianças e esperar que todos os alunos se alimentassem antes de entrar na fila. O professor mortificado pelo julgamento docente encontra, depois de alguns minutos infindáveis, um modo de romper com aquela reunião, alegando uma prova surpresa ao pé do ouvido da diretora.

Curiosamente, o refeitório virou espaço de conversas entre alunos e professores, e a prova surpresa nunca foi feita.

\section{arrombo da escuta}

Talvez aqui devêssemos fazer uma nota.

Durante todo o tempo nas escolas, duas coisas se tornaram bem evidentes: a questão da escola, certamente, não é a de silenciar os alunos. Nas duas escolas, vimos diversas tentativas de criar canais de escutas com os alunos. É de se dar crédito, por exemplo, ao processo de criação de assembleias estudantis e também o de criação de um grêmio estudantil nas escolas. Esse processo, decerto, não é pouco trabalhoso.

Contudo, parece haver escutas para alunos e alunas específicos.

Esse é o grande ponto.

Se nas escolas é mais provável que se escute a aluna "certinha" ou o aluno nerd, é preciso olhar quais são as táticas de criação de escutas desses corpos-alunos que nada têm de "certinhos".

Conforme Carvalho e Roseiro (2015) discutem, existem corpos que, no decorrer da vida escola, deixam de ser alunas e alunos, para ocupar um lugar de "julgamento", onde lhes é retirada a possibilidade de resposta. No entanto, como também é evidente, esses corpos são retirados das salas justamente por arrombar escutas, isto é, por não falar de acordo com os tons esperados. Se existe mesmo 
escola, problemas de escuta?

essa possibilidade destacada pelos autores de colocar certos corpos a nu nos termos agambenianos, esses mesmos alunos fazem de sua nudez gritos públicos.

Não importa o lugar, os arrombos da escuta continuam a se expandir: são escritos nas mesas sobre alguma lógica louca da escola; são pichações nas portas dos banheiros que dizem verdades cruas sobre a diretora; são caricaturas feitas no verso das provas; são alunos que arrombam a porta no chute quando a professora diz que nenhum deles sairá para comer no recreio.

Se são os alunos certinhos que mantêm a preferência da escuta, os bagunceiros de prontidão sabem muito bem fazer amizades, torrar a paciência do nerd da turma ou, quem sabe, ganhar a representação estudantil de suas turmas. Por vezes, o arrombo não é um ato violento, mas apenas uma jogada coletiva.

Nesses casos, o surto da escola parece ser ainda maior.

No fim do ano, um aluno de uma das escolas criou coragem para dizer a sua professora que ela era racista. Não houve tom acusatório ou mesmo uma tentativa de ofensa. O menino - um negro muito grande para sua idade realmente parou do lado dela e contou um caso que ocorreu com ambos, dizendo que, para ele, aquilo era um traço de racismo. "Lembra quando você me colocou para fora e pediu uma suspensão da sua aula? Pô, eu tinha levado uma borrachada na cara e você não fez nada, 'fessora. Eu falei com você e você não fez nada. Aí quando eu joguei nas costas dele, você me colocou pra fora e pediu suspensão. Não é um pouco estranho?" O aluno não estava sozinho; ali, do lado dele, estava o outro menino envolvido na história. Um era branco e o outro era negro. Diante da professora, naquele momento, nenhum dos dois ria, mas também não tinha o menor resquício de rancor. "Só queria mesmo que você pensasse nisso", o menino concluiu. A professora olhou de um para outro, agradeceu pelo aviso e desconversou, mas, no fim do dia, ainda se matutava sobre aquilo.

Às vezes, os arrombos são essas falas que, mesmo cordiais, impedem nossas escutas de se afinarem. Podemos até não ter condições de ouvi-los, mas a insistência cacofônica nesses casos é tão grande, que qualquer voz afinada perde o controle. 


\section{vozes sem tom?}

Em um diálogo gravado e transcrito no fim do século XX, Gilles Deleuze e Claire Parnet (1998, p. 12) discutem sobre a conversa e, não por um acaso, chegam a afirmar que, ao conversar com um livro, não se pode ter uma pretensão de postura ou de entendimento. "A boa maneira de se ler", dizem eles, "é a de conseguir tratar um livro como se escuta um disco, como se vê um filme ou um programa de televisão", isto é, não na intenção de compreender ou intervir em algo, mas de modo a sentir a vida.

Isso, justamente, é como apostamos pensar a escuta.

Se dissemos antes que a escola, socialmente, foi imbuída de especificidades, não podemos discordar disso. A escola tem, sim, um papel. Todavia, acreditamos mais na perspectiva de uma escola capaz de escutar o mundo em seus ruídos, gemidos, sussurros, balbucios, choros, gagueiras, gritos, grunhidos, enfim, com amplas possibilidades sonoras e com os tons mais variados.

Aqui, a escola encontra, nesses barulhos produzidos pelo mundo, a sua função sensível, isto é, a sua função de cuidar do mundo, transformando-o para além da ordem e do progresso estabelecidos.

$\mathrm{Na}$ bagunça, os conceitos que se firmam repletos de saber perdem seu tom dogmático. Diante das piadas, brincadeiras, conversinhas de fundo de sala, gritarias no pátio, jogos na quadra, beijos escondidos na biblioteca, talheres arranhando pratos, apontamentos contextualizados ou não, falas esquecidas, enfim, ante toda barulhidade, a escola não pode ser um espaço militarizado. Se o Decreto 9.465, de 02 de janeiro de 2019, prevê que as escolas cívico-militares sejam promovidas, fomentadas, acompanhadas e avaliadas enquanto modelo de escola a ser aderido pelos sistemas de ensino municipais e estaduais (BRASIL, 2019, art. 11, inciso XVI), propomos, em contrapartida, ensinar a fazer dessa balburdia cacofônica um modo sensível de encontrar a vida.

Afinal, apenas a vida vagabunda é capaz de fazer travessuras.

Em 1947, Fernand Deligny (2018) publica um livro maravilhoso, intitulado Os vagabundos eficazes, em que faz um relato sobre seu período como diretor de um instituto de educação-correção de jovens. E, para que não restem dúvidas, Deligny 
escola, problemas de escuta?

acusa largamente seus alunos de vagabundos que ora fogem do trabalho, por isso aparecem à sua porta, ora fazem fanfarra pelas ruas, por isso são impedidos de fazer boas figuras públicas.

Em resposta, os alunos apontam-no como o maior dos crápulas.

Seja como for, Deligny mostra-nos, em seu trabalho, justamente o quanto a vagabundagem é indecorosa e, por isso mesmo, feia até seu último fio de cabelo, desordeira, travessa. O corpo-vagabundo é da ordem da delinquência, da insensatez, mantendo, em suas ações, o máximo possível do deboche.

Para se proteger da polícia e da prisão por reincidência, os meninos do Centro que iam à cidade levavam no bolso uma permissão devidamente datada e carimbada. Com essa permissão, exibida em qualquer ocasião, tentavam conseguir meia-entrada no cinema, dar voltas gratuitas nos carrosséis das feiras, não pagar o bonde, evitar fila nos guichês da estação de trem. E eles eram tão persuasivos, em sua alegria elementar de estar "em ordem" na participação de um grupo, que a extravagância do oportunismo encontrava pouca resistência (DELIGNY, 2018, p. 67).

Talvez, justamente nessa cena, pensemos nos corpos-vagabundos de escola. A questão em evidência não é a do vagabundo como aquele que abusa de sua malandragem, de modo a ferir as pessoas ou aquele que nada quer fazer. Ao contrário, o vagabundo é essa figura que brinca com as coisas sérias sem medo da imagem que possa produzir de si. É, por exemplo, aquele menino que, travesso, abraça a professora, lhe dá milhares de beijos para simplesmente conseguir ganhar uma bala. Não é nem de longe o menino mais comportado ou mesmo o que mais participa das aulas; todavia, é daqueles que colocam sempre um sorriso no seu rosto, por fazer algo que, sob certas lógicas, não deveria.

As crianças vagabundeiam simplesmente por questionar o sentido da ordem.

O termo incomoda, faz-nos pensar nas piores coisas. É preciso reconhecermos que, ao pensarmos na figura do vagabundo, a imagem que nos surge é do corpo à toa, do corpo delinquente.

E, entretanto, a vagabundagem faz, antes, juras de amor às inquietações, às perguntas que não permitem respostas pré-fabricadas. Em uma única fala, por exemplo, um aluno pergunta se existem larvas vivendo no magma, pergunta por 
que não fazemos o processo de metamorfose dos insetos e ainda comenta as escaladas dele sobre os telhados das casas perto da igreja.

Diante de tal cenário, a escuta objetivada se perde, e o professor, se demasiado interessado, responde a apenas uma das perguntas ou logo manda o aluno prestar atenção.

Mas é preciso fazer uma ressalva: a vagabundagem não é simpática à ordem. Não se iludam pensando que vão encontrar corpos-vagabundos sorridentes e dizendo "sim, senhor" ou "sim, senhora" nos corredores das escolas. Eles, quando cruzam conosco, usam tons cômicos, apelidos, cumprimentos estranhos.

Numa das escolas, uma aluna passa pelo corredor e, imediatamente, a coordenadora dá um salto. "Que short é esse?", perguntou ela com seu tom mais controlador possível. "É o meu. Bonito, né?", respondeu a aluna simpática. “Vai trocar isso agora!". E, gentilmente, a aluna seguiu para o banheiro. Alguns minutos depois, a aluna voltou, sorridente, com um short ainda menor. "Que merda é essa?", perguntou a coordenadora, horrorizada. "Eu troquei", disse a aluna. "Por um ainda menor!", gritou a coordenadora. "Isso mesmo", falou a aluna. “E, se me mandar trocar de novo, eu vou arranjar um ainda menor que já está até separado na minha bolsa". "É IMPOSSÍVEL!". "Pois não me teste”, finalizou a aluna.

Para deixar claro: a aluna foi mesmo obrigada a trocar de novo. Inclusive, deram-lhe a parte de baixo do uniforme. Todavia, ainda assim, quando ela saiu do banheiro, a coordenadora não pôde deixar de soltar um grito: o short estava dobrado em mil pedaços e estava mais curto que os dois anteriores.

Às vezes, por outro lado, caímos na história das roupas das mães. Vira e volta, a coordenadora de uma dessas escolas se aventurou a ligar para a família diante do ultraje da roupa curta. "Quantas vezes já lhe disse para não vir para a escola com esse shortinho?", esbravejou a coordenadora. E, imediatamente, vai para a secretaria fazer uma ligação pretensamente emergencial. Mas a situação é quase sempre a mesma: a figura que aparece na escola é, claramente, a mãe da menina - suas roupas apenas diminuem. 
escola, problemas de escuta?

Por conseguinte, a coordenadora sempre se irritava. Acreditava, piamente, estar certa sobre o respeito às vestimentas. O que ela não percebeu, por sua vez, foi o quanto, nalguns casos, as imitações produzem efeitos insurrecionais.

De certo modo, alunas e alunos dados à travessura fazem isso o tempo inteiro: provocam pequenas insurreições escolares.

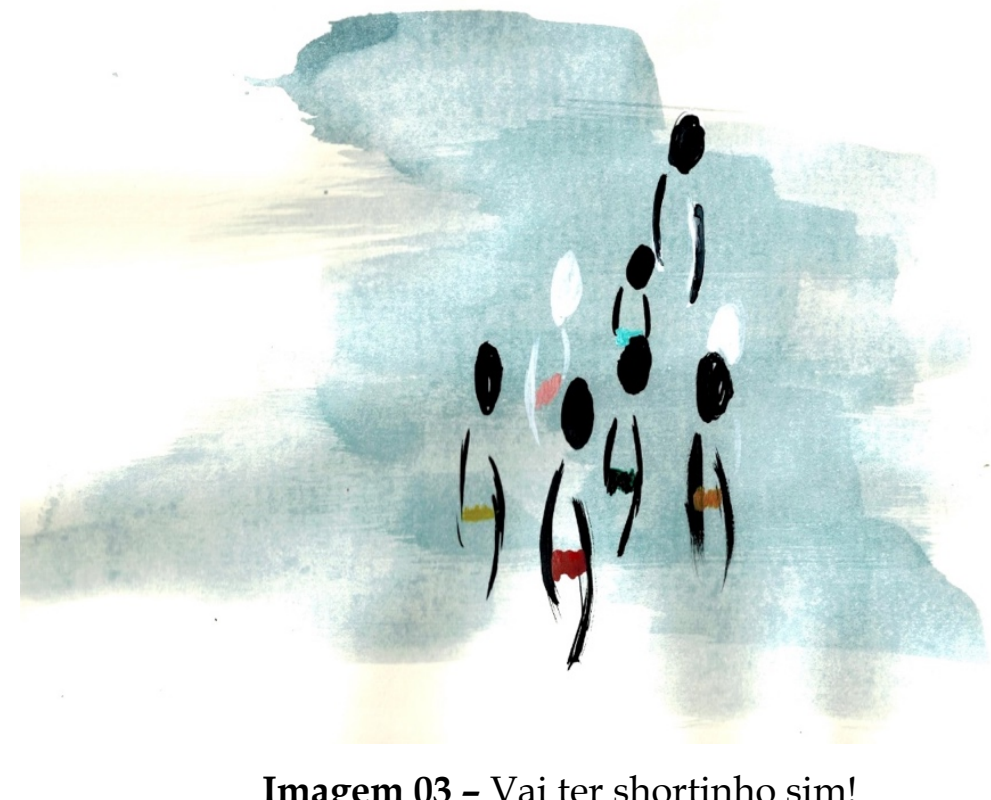

Imagem 03 - Vai ter shortinho sim!

O Comitê Invisível (2016) propõe pensar que a insurreição não é a simples revolta. Logicamente, há um tom de revolta no ato insurrecional. Porém, a insurreição prevê corpos em conjunto, prevê uma ação entre pessoas com algo em comum. Na outra escola, por exemplo, essa cena do short foi também vivida por um grupo de meninas que, liberadas do uniforme para fazer um trabalho com tinta acrílica, vestiram shorts considerados muito curtos pela coordenação. Entretanto, ali, as meninas se juntaram. Elas não tiveram a ousadia da menina da outra escola de diminuir mais e mais o tamanho da vestimenta, mas também não aceitaram passivamente a voz da ordem. Reunindo todas as colegas de short e o professor delas, elas partiram para cima da coordenadora com olhar desafiador. A coordenadora cedeu, deixando com o professor apenas o aviso de que não esperava ver nenhuma delas de novo.

Assim que chegaram à sala, a turma rendeu uma conversa sobre vestimentas, feminismo, lutas e sobrevivência da mulher de modo primordial. 
Nunca, antes, o professor tinha sentido firmeza em falar sobre esses assuntos com as crianças; contudo, ali estavam elas, dizendo-lhes, claramente, que aquilo não poderia passar despercebido.

Isso é o quê insurrecional, essa força que diz "BASTA!" para o controle, para as escutas afinadas e amarras padronizadas.

A insurreição tem a ver com essa escuta distraída que percebe os limites do corpo. Quando conseguimos ouvir os gemidos, os sussurros que dizem "De novo?" em tom lamentoso, é, enfim, quando podemos dar ouvidos à insurreição.

\section{escutar com a pele}

Na era da emancipação, da consciência, do trabalho e da coletivização da vida, o aluno perfeito é aquele que, individualmente, se isola e imita por um objetivo específico. E, sendo essa criança uma devota dos ideais da escola que vangloria o "humano", ela pode, enfim, falar e ser ouvida. Imitando todos os padrões lógicos da humanidade, ela, finalmente, fala nos conformes do coral regiamente orquestrado. De algum modo, espera-se que essa imitação seja, a um só tempo, inovadora e criativa.

Curiosamente, é nesse contexto de repetir esse estigma e de valorizar essa condição do humano que algumas teorias enaltecem a revolução.

Aí, talvez, alunas e alunos vejam, enfim, o fracasso dessa escola desconexa.

Daí dizemos: toda vez que uma criança grita em sala sem qualquer motivo dito racional, que uma mãe ensina a sua filha a falar sempre mais alto ou que um grupo de adolescentes se reúne para escrever cartas malcriadas à escola, vemos, certamente, quês de insurreição que forçam a existência de escutas desatentas.

Ora, os insurgentes atravessam a linearidade aos risos e aos saltos. Se se espera que a humanidade seja linear, esses corpos produzem rompantes animalescos, descobrem-se em meio a máquinas e não pretendem dominá-las; sabem-se apenas mais um corpo entre outros tantos, e isso não lhes ofende.

Riem-se de todo o desejo libertário.

$\mathrm{Na}$ insurreição, liberdade é a possibilidade de fazer contágio com outros corpos. 
escola, problemas de escuta?

Ambos, vagabundo e insurrecto, recorrem à escuta a partir de tons e encantamentos que uma escuta distraída dá corda. Corpos verdadeiramente vivos arrombam as escutas afinadas.

Ali onde se esperaria feiura, encontra-se algo belo: a própria vida. Ao vagabundo, ao animalesco e ao insurgente o mundo e a vida são mais sensíveis, e a ordem serve para ser rompida por muitas travessuras, já que não lhes interessa nova ordem. Preferem, antes, bagunça na zoeira do que é viver.

\section{referências}

BAPTISTA, Luis Antônio Santos. A atriz, o padre e a psicanalista. Os amoladores de facas. Anuário do Lasp, Niterói, v. 1, n. 3/4, p. 103-109, 1997.

BRASIL. Decreto 9.465, de 2 de janeiro de 2019. Presidência da República. Disponível em: <https://www.conjur.com.br/dl/decreto-9465-janeiro-2019-ensino-militar.pdf>. Acesso em: 15 jan. 2019.

CARVALHO, Janete Magalhães; ROSEIRO, Steferson Zanoni. Vida nua, vida-criança, vida-aluno: rastros de identidade e diferença afirmando um "estado de exceção". Currículo sem Fronteiras, v. 15, n. 3, p. 599-613, set./dez. 2015.

COMITÊ INVISÍVEL. Aos nossos amigos: crise e insurreição. Trad. Edições Baratas. São Paulo: n-1 edições, 2016.

COMITÊ INVISÍVEL. Motim e destituição agora. Trad. Vinicius Honesko. São Paulo: n-1 edições, 2017.

DELEUZE, Gilles; GUATTARI, Félix. Kafka: por uma literatura menor. Trad. Cíntia Vieira da Silva. Belo Horizonte: Autêntica Editora, 2014.

DELEUZE, Gilles; GUATTARI, Félix. O anti-Édipo: capitalismo e esquizofrenia 1. Trad. Luiz B. L. Orlandi. 2. ed. São Paulo: Ed. 34, 2011.

DELEUZE, Gilles; PARNET, Claire. Diálogos. Trad. Eloísa Araújo Ribeiro. São Paulo: Editora Escuta, 1998.

DELIGNY, Fernand. Os vagabundos eficazes: operários, artistas, revolucionários: educadores. Trad. Marlon Miguel. São Paulo: n-1 edições, 2018.

ENGELS, Friedrich. O papel do trabalho na transformação do macaco em homem. Trabalho necessário, v. 4, p. 1-9, 2006.

KAFKA, Franz. Um relato para a academia. In: KAFKA, Franz. Um médico rural. São Paulo: Companhia das Letras, 1999. p. 59-72.

LARROSA, Jorge. Linguagem e educação depois de Babel. Trad. Cynthia Farina. 2. ed. Belo Horizonte: Autêntica Editora, 2014.

LAZZARATO, Maurizio. Signos, máquinas, subjetividades. Trad. Paulo Domenech Onetto. São Paulo: n-1 edições; SESC, 2014.

MASSUMI, Brian. O que os animais nos ensinam sobre politica. Trad. Francisco Trento e Fernanda Mello. São Paulo: n-1 edições, 2017.

RANCIÈRE, Jacques. O mestre ignorante. 5 lições sobre a emancipação intelectual. Trad. Lilian do Valle. 3. ed. Belo Horizonte: Autêntica Editora, 2013.

SAVIANI, Demerval. Pedagogia histórico-crítica: primeiras aproximações. 11. ed. Campinas: Autores Associados, 2011.

VYGOTSKY, Lev Semenovich. Obras escogidas. T. 5. Fundamentos de la defectologia. Espanha: Antonio Machado, 2012. 